\title{
PERBEDAAN EFEKTIVITAS CHLORHEXIDINE GLUKONAT 0,2\% DENGAN TEH HIJAU (CAMELLIA SINENSIS) TERHADAP JUMLAH PORPHYROMONAS GINGIVALIS
}

Devi Dwipriastuti*., R. Rama Putranto ${ }^{* *}$., Welly Anggarani ${ }^{* *}$

Keywords:

Green tea extract,

Chlorhexidine gluconate

$0.2 \%$, Porphyromonas gingivalis

\section{ABSTRACT}

Background: Periodontitis is a periodontal inflammation caused by plaque that contains pathogens, Porphyromonas gingivalis is one of them. Chlorhexidine therapy used to reduce the number of pathogenic bacteria causing periodontitis. Green tea contains polyphenols such as epigallocatechin-3-gallic as antibacterial agent that can kill the bacteria Porphyromonas gingivalis. This study aims to determine differences in the effectiveness of chlorhexidine gluconate $0.2 \%$ with green tea (Camellia sinensis) various concentrations to decrease the amount of bacteria Porphyromonas gingivalis.

Method: This research was experimental with post test only design. Method used in antibacterial test was a drop plate misra. The experimental group consisted of six groups: chlorhexidine gluconate $0.2 \%$ and green tea group with a concentration of $100 \%, 75 \%, 50 \%, 25 \%$ and $12.5 \%$. minimum bactericidal concentrations againts Porphyromonas gingivalis was evidenced by counting the number of colonies that formed on agar. Analysis data was using One Way ANOVA continued by Post hoc tests Tamhane.

Result: The results showed that chlorhexidine gluconate $0.2 \%$ with green tea effective to decrease the amount of bacteria Porphyromonas gingivalis(ANOVA $\mathrm{p}<0.05)$. The results between the groups showed green tea $100 \%, 75 \%$ and $25 \%$, have same effect compared to chlorhexidine gluconate $0.2 \%$ in reducing Porphyromonas gingivalis.

Conclusion: In this experiment showed that chlorhexidine gluconate $0.2 \%$ and green tea extract $100 \%, 75 \%, 50 \%, 25 \%$ and $12.5 \%$ were able to decrease the amount of Porphyromonas gingivalis.

\section{PENDAHULUAN}

Penyakit mulut yang sering ditemui adalah penyakit periodontal dengan insidensi mencapai $5 \%$ - 20\% dari populasi dewasa di dunia 1. WHO juga menyebutkan bahwa penyakit periodontal merupakan penyakit mulut yang paling sering terjadi setelah karies. Periodontitis merupakan salah satu klasifikasi dari penyakit periodontal dimana terjadi respon host terhadap akumulasi plak yang melekat di permukaan gigi dan gingiva pada dentogingival junction yang mengandung berbagai mikroorganisme. Periodontitis ditandai dengan adanya inflamasi pada jaringan periodontal dimana terlihat kehilangan perlekatan yang agresif dan kerusakan pada tulang alveolar. Bakteri patogen pada jaringan periodontal meliputi bakteri Prevotela, Porphyromonas dan Fusobacterium spp. ${ }^{2}$

Porphyromonas gingivalis adalah bakteri gram-negatif anaerob yang merupakan flora normal di dalam rongga mulut manusia yang banyak ditemukan pada area sulkus gingiva, plak subgingiva, lidah dan tonsil. Penggunaan 
chlorhexidine sebagai obat kumur efektif digunakan sebagai anti plak dan juga antibakteri yang dapat mengurangi keparahan dari peradangan gingiva ${ }^{3,4}$.

Chlorhexidine glukonat merupakan obat kumur yang sering digunakan pada masyarakat luas, chlorhexidine sendiri merupakan suatu zat antibakteri dengan sifat bakterisida dan efektif untuk bakteri gram positif dan gram negatif ${ }^{5,6}$. Penggunaan chlorhexidine sebagai antiseptik ternyata diketahui memiliki efek samping jika digunakan dalam jangka waktu yang lama, seperti pewarnaan pada gigi, adanya sensasi dan rasa yang tidak enak ${ }^{2}$.

Teh hijau memiliki kandungan polifenol dengan senyawa katekin, Kandungan katekin terbanyak pada teh hijau berupa EGCG yaitu sekitar 50-80\%. EGCG bekerja aktif dalam menekan terjadinya inflamasi, membunuh dan menghambat berbagai mikroorganisme dan memiliki kemampuan sebagai antioksidan ${ }^{7,8,9}$.

\section{METODE PENELITIAN}

Jenis penelitian yang digunakan adalah penelitian eksperimental murni, dengan rancangan penelitian post-test only. Kelompok penelitian dibagi kedalam 6 kelompok, yaitu kelompok teh hijau konsentrasi 100\%, 75\%, $50 \%, 25 \%, 12,5 \%$ dan chlorhexidine glukonat $0,2 \%$. Penelitian ini dilakukan pada bulan
Oktober hingga November 2016. Sampel yang digunakan adalah bakteri Porphyromonas gingivalis yang selanjutnya dibuat menjadi suspensi dengan kekeruhan 0,5 Mc Farland. Sebelum dilakukan perlakuan, dibuat ekstraksi teh hijau menjadi teh hijau konsentrasi $100 \%$, $75 \%, 50 \%, 25 \%$ dan $12,5 \%$ dengan diencerkan aquabidest.

Penentuan KBM dilakukan pada pada teh hijau konsentrasi $100 \%, 75 \%, 50 \%, 25 \%$, $12,5 \%$ dan chlorhexidine glukonat $0,2 \%$, bahan coba dengan konsentrasi diatas diambil sebanyak $1 \mathrm{ml}$ dan ditambahkan dengan media $\mathrm{BH}$ sebagai penyubur bakteri lalu dimasukkan ke dalam tabung reaksi kemudian diberi label sesuai konsentrasi. Suspensi bakteri yang telah dipersiapkan sebelumnya diambil $1 \mathrm{ml}$ lalu dimasukkan ke dalam masing-masing tabung bahan coba yang telah diberi label kemudian divorteks hingga homogen, kemudian diambil $50 \mu l$ dan diteteskan pada MHA. Inkubasi dalam inkubator secara anaerobik selama 48 jam. Perhitungan jumlah koloni secara viable atau yang terlihat dengan mata pada cawan petri. Selanjutnya hasil perhitungan dilakukan analisis data dengan uji One Way Anova.

\section{HASIL PENELITIAN}

Hasil pengamatan jumlah koloni bakteri Porphyromonas gingivalis yang dihitung

Tabel 1. Rata-rata jumlah koloni bakteri Porphyromonas gingivalis

\begin{tabular}{lc}
\hline & Rata-rata \\
\hline Chlorhexidine Glukonat $0,2 \%$ & 1 koloni \\
Teh Hijau $100 \%$ & 6 koloni \\
Teh Hijau $75 \%$ & 40 koloni \\
Teh Hijau 50\% & 63 koloni \\
Teh Hijau 25\% & 95 koloni \\
Teh Hijau 12,5\% & 234 koloni \\
\hline
\end{tabular}


secara visual oleh tiga orang independent pada cawan petri.

Hasil penelitian yang diperoleh kemudian dilakukan analisis data statistik dengan uji One Way Anova. Sebelum dilakukan uji analisa statistik, dilakukan uji normalitas dengan menggunakan uji Shapiro-Wilk, uji ini digunakan karena sampel yang digunakan kurang dari 50 sampel. Dari uji normalitas dengan menggunakan uji Shapiro-wilk didapatkan chlorhexidine glukonat $0,2 \%$ dan teh hijau konsentrasi 100\%, 75\%, 50\%, 25\% dan $12,5 \%$ memiliki nilai ( $p>0,01)$ yang berarti data berdistribusi normal. Setelah itu dilakukan uji homogenitas dengan menggunakan Uji Levene's Test. Dari hasil uji homogenitas didapatkan bahwa nilai $(p<0,05)$ yang menandakan bahwa data dalam penelitian ini memiliki varian yang tidak sama. Dari hasil uji homogenitas dan uji normalitas didapatkan hasil data yang normal namun tidak homogen maka dilakukan uji paramaterik One Way Anova dan dilanjutkan dengan Post hoc Tamhane's

Dari uji parametrik One Way Anova, didapatkan hasil $(p<0,05)$ yang berarti Chlorhexidine glukonat $0,2 \%$ dan Teh hijau konsentrasi $100 \%, 75 \%, 50 \%$, 25\% dan $12,5 \%$ memiliki pengaruh yang signifikan terhadap penurunan jumlah bakteri Porphyromonas gingivalis. Selanjutnya dilakukan uji Post hoc Tamhane's untuk mengetahui perbedaan antar kelompok. Hasil pengujian Post hoc Tamhane's didapatkan nilai signifikansi $p>0,05$ antara Chlorhexidine glukonat $0,2 \%$ dengan teh hijau konsentrasi 100\% (sig. ,864), 75\% (sig. ,152),
25\% (sig. ,410) maka terdapat pengaruh yang sama antar kedua bahan yang sama terhadap pertumbuhan jumlah bakteri Porphyromonas gingivalis.

\section{DISKUSI}

Hasil uji Anova yang dilakukan didapatkan nilai $p<0,05$ yang menandakan Chlorhexidine glukonat $0,2 \%$ dan Teh hijau konsentrasi $100 \%, 75 \%$, 50\%, 25\% dan 12,5\% memiliki pengaruh terhadap pengurangan jumlah koloni bakteri Porphyromonas gingivalis. Adanya pengaruh dari teh hijau dikarenan adanya kandungan EGCG pada teh hijau yang berperan sebagai antibakteri yang efektif dalam menghambat pertumbuhan bakteri Porphyromonas gingivalis ${ }^{10}$. Selanjutnya pada uji Post hoc Tamhane's didapatkan nilai $p>0,05$ pada Chlorhexidine glukonat $0,2 \%$ dengan teh hijau konsentrasi 100\%, 75\%, $25 \%$ dimana dapat diartikan bahwa masingmasing konsentrasi memiliki pengaruh yang sama seperti chlorhexidine glukonat 0,2\% dalam pertumbuhan bakteri Porphyromonas gingivalis. Pada penelitian sebelumnya yang dilakukan oleh Mageed disebutkan bahwa teh hijau konsentrasi $100 \%$ dan $90 \%$ memiliki daya antibakteri yang sama dalam melawan bakteri Porphyromonas gingivalis. Pada penelitian lain yang dilakukan oleh Antoniazzi mengatakan bahwa chlorhexidine memiliki efektivitas yang lebih baik dari teh hijau dengan konsentrasi $10 \%$. Berdasarkan hasil data statistik teh hijau konsentrasi $25 \%$ sudah dapat memiliki efek

Tabel 2 One Way Anova

\begin{tabular}{lrr}
\hline & F & \multicolumn{1}{l}{ Sig. } \\
\hline Between Groups & 18,304 &, 000
\end{tabular}


antibakteri yang setara dengan chlorhexidine glukonat $0,2 \%{ }^{11,12}$.

Penghitungan jumlah koloni bakteri pada penelitian ini dilakukan dengan perhitungan secara visual oleh tiga pengamat independent. Dimana perhitungan jumlah koloni menggunakan metode drop plate dengan teknik mills misra, pada metode hitung cawan ini diasumsikan bahwa jumlah bakteri yang ada dalam cawan sama dengan jumlah koloni pada cawan tersebut. Perhitungan jumlah koloni dengan metode ini mengunakan anggapan bahwa setiap sel akan hidup berkembang menjadi satu koloni, koloni yang berkelompok ataupun membentuk rantai dapat dihitung dua koloni jika masih dapat dibedakan ataupun tidak menjadi satu ${ }^{13}$. Penggunaan metode drop plate ini dengan cara meneteskan larutan bakteri dan ekstrak ke cawan petri, terdapat beberapa faktor mikrobiologi yang berpengaruh terhadap keberhasilan penelitian ini diantaranya spesies bakteri, strain dan kondisi bakteri untuk tumbuh (agar, suhu waktu dan media yang digunakan). Metode ini diharapkan dapat membantu penghitungan bakteri lebih cepat dan akurat selain itu penggunaan metode mills misra lebih sering digunakan karena tidak menyebabkan bahaya untukoperator, namun dalam melakukan inokulasi dan membaca jumlah koloni yang tumbuh pada media agar dibutuhkan ketelitian yang baik dan pengalaman dari operator ${ }^{14}$.

Kemampuan antibakteri dari teh hijau dikarenakanadanyakandungan polifenolberupa EGCG yang dapat menyebabkan kerusakan irreversible pada membran sel bakteri, selain itu EGCG juga dapat menghambat transkrip DNA bakteri sehingga menyebabkan kematian sel bakteri ${ }^{10}$. Chlorhexidine glukonat memiliki kandungan biguanid dengan muatan kation (muatan positif) yang besar sementara sebagian besar bakteri memiliki muatan anion (muatan negatif). Hal ini menyebabkan chlorhexidine dapat berikatan baik dengan bakteri dan menyebabkan perubahan permeabilitas membran sel bakteri yang selanjutnya terjadi kematian sel karena keluarnya sitoplasma sel bakteri. Teh hijau dan chlorhexidine glukonat memiliki dua mekanisme tersendiri sebagai antibakteri namun kedua bahan ini terbukti dapat menghambat perlekatan bakteri Porphyromonas gingivalis ${ }^{15}$.

\section{KESIMPULAN}

1. Terjadi penurunan jumlah bakteri porphyromonas setelah diberikan chlorhexidine glukonat $0,2 \%$

2. Jumlah bakteri Porphyromonas gingivalis setelah diberikan ekstrak teh hijau konsentrasi $100 \%$ dan $75 \%$ memiliki rerata paling rendah dibandingkan dengan teh hijau konsentrasi lain yaitu 6 koloni bakteri untuk ekstrak teh hijau 100\% dan 40 koloni bakteri pada ekstrak teh hijau 75\%

3. Ekstrak teh hijau 100\%, 75\% dan 25\% memiliki efektivitas setara dengan Chlorhexidine glukonat $0,2 \%$ dalam membunuh bakteri Porphyromonas gingivalis, hal ini dapat terlihat dari penurunan jumlah bakteri pada cawan petri.

\section{DAFTAR PUSTAKA}

1. Wu, Ying-Ying, Xiao, E. dan Graves, Dana T. Diabetes Mellitus Related Bone Metabolism And Periodontal Disease. International Journal Of Oral Science. 2015. 7:63-72

2. Marsh, P. D., Martin, M. V. Oral Microbiology. ed ke-5. London: Churchill Livingstone Elsevier; 2009.

3. Nirmaladewi, A., Handajani, J. dan Tandelilin, Regina TC. Status Saliva dan Gingivitis Pada Penderita Gingivitis Setelah Kumur Epigalocatechingallate (EGCG) Dari Ekstrak Teh Hijau (Camellia Sinensis). 
Bagian Biologi Mulut FKG UGM. 2003.

4. Balagopal, Shruti dan Arjunkumar, Radhika. Chlorhexidine: The Gold Standard Antiplaque Agent. Journal Of Pharmaceutical Sciences And Research. 2013. 5(12): 270-274.

5. Soeherwin, M., Muthalib, A. dan D.,Ariadna. Efek Kumur dengan Chlorhexidine Glukonat $0,2 \%$ Sebelum Tindakan Operasi Molar 3 terhadap Bakterimia. Dental Horison. 2000. 2(8):1-8.

6. Anggayanti, Nyoman A., Adiatmika, IPG., Adiputra, Nyoman. Berkumur dengan teh hitam lebih efektif daripada chlorhexidine gluconate $0,2 \%$ untuk menurunkan akumulasi plak gigi. Jurnal PDGI. 2013. 62(2):35-40.

7. Setiawan, D. M., Masria S. dan Chrysanti. Daya Antibakteri dan Waktu Kontak Infusa Teh Hijau (Camellia sinensis) Terhadap Salmonella typhi. MKB. 2010. 42(2):51-55.

8. Widyaningrum, Naniek. Epiggalocatechin-3-Gallate (EGCG) Pada Daun Teh Hijau Sebagai Anti Jerawat. Majalah Farmasi dan Farmakologi. 2013. 17(3):9598.

9. Saryono. Potensi Teh Hijau Dalam Penyembuhan Luka: Sistematik Review. Prosiding Konferensi Nasional PPNI Jawa Tengah 2013. 2013. 202-205.

10. Araghizadeh, Abdolmehdi. Kohanteb, Jamshid. Fani, Mohammad Mehdi. Inhibitor Activity of Green Tea (Camellia sinensis) Extract On Some Clinically Isolated Cariogenic and Periodontopathic Bacteria. Medical Principles and Practice. 2013. 22: 368-372.
11. Mageed, J. Mays. Juma, S. S. S. Antimicrobial effects on green tea extracts on Porphyromonas gingivalis (in vitro study). IOSR Journal of Dental and Medical Sciences. 2015. 14(10): 33-39.

12. Antoniazzi, R. Pippi. Trojahn, G. Ocampo. Casarin, Maísa. Oxygen tension during biofilm growth influences the efficacy antimicrobial agents. Rev Odontol UNESP. 2016. 45(5): 302-307.

13. Wijaya, Raden Candra. Utari, E. Lusiana. Yudianingsih. Perancangan Alat Penghitung Bakteri. Jurnal Teknologi Informasi. 2015. 10(29): 59-67.

14. Herigstad, Becky. Hamilton, Martin. Heersink, Joanna. How to optimize the drop plate method for enumerating bacteria. Journal of Microbiological Methods. 2000. 44(2001): 121-129.

15. Sinaredi, B. Rizki. Pradopo, Seno. Wibowo, Teguh Budi. Daya antibakteri obat kumur chlorhexidine, povidone iodine, fluoride suplementasi zinc terhadap, Streptococcus mutant dan Porphyromonas gingivalis. Dental Journal. 2014. 47(4): 211-214. 